TEME, г. XLV, бр. 1, јануар - март 2021, стр. 247-263

\begin{tabular}{lr}
\hline Оригинални научни рад & https://doi.org/10.22190/TEME1910310470 \\
Примљено: 31. 10. 2019. & UDK 618.112:316.647-057.87
\end{tabular}

Ревидирана верзија: 25. 5. 2020.

Одобрено за штампу: 26. 2. 2021.

\title{
EGG DONATION: EXPLORING ATTITUDES OF STUDENTS TOWARDS DONATION
}

\author{
Jelena Opsenica Kostić*, Milica Mitrović, Damjana Panić \\ University of Niš, Faculty of Philosophy, Niš, Serbia
}

\begin{abstract}
Conception with donated oocytes represents an important option for overcoming sterility, but brings with it numerous dilemmas, which have been dealt with differently in various European countries. In the Republic of Serbia, anonymous oocyte donation is legal, and donors include women from the general population, and women undergoing IVF. This is a new phenomenon in our society, for which the law requires promotion. In order for the campaign to be appropriate, it is necessary to learn about existing attitudes. This research was carried out with the aim of determining the attitudes of students towards egg donation $(\mathrm{N}=503 ; 206$ young men, 297 young women). A questionnaire was used, designed based on the scale used by Swedish authors to study the attitudes of potential donors (Skoog-Svanberg, Lampic, Bergh, \& Lundkvist, 2003). The obtained results indicate that there are generally positive attitudes towards oocyte donation, but that most respondents are reserved regarding the issue of propagating donors in the media. Most of the respondents are unsure regarding donation from IVF, and when asked about donor anonymity and the right of the child to learn its genetic origin, they showed signs of oscillating and supporting contradictory options. Even though this study was carried out on a student population, it is possible to identify significant guidelines for the start of the promotion of voluntary egg donation in RS, as well as implications for future research.
\end{abstract}

Key words: $\quad$ egg cell donation, attitudes towards donation, potential donors, donor promotion, students.

\section{ДОНИРАЊЕ ЈАЈНИХ ЋЕЛИЈА: ИСТРАЖИВАЊЕ СТАВОВА СТУДЕНАТА ПРЕМА ДОНИРАҢУ}

Апстракт

Зачеће помоћу донираних јајних ћелија представља значајну могућност превазилажења стерилитета, али доноси са собом и неке дилеме, које су различито решене у европским земљама. У Републици Србији је дозвољено анонимно добровољно дони-

\footnotetext{
* Аутор за кореспонденцију: Јелена Опсеница Костић, Филозофски факултет, Ћирила и Методија 2, 18000 Ниш. Србија, jelena.opsenica.kostic@filfak.ni.ac.rs
} 
рање ооцита, а донори могу бити жене из опште популације и жене укључене у ВТО процес. Ово је нов феномен у нашем друштву, за који и са̂м закон предвиђа промоцију. Да би кампања била одговарајућа, неопходно је упознати актуелне ставове. Ово истраживање спроведено је у циљу истраживања ставова студената према донирању јајних ћелија ( $\mathrm{N}=503 ; 206$ младића, 297 девојака). Употребљен је упитник направљен по угледу на скалу шведских аутора за испитивање ставова могућих донора (Skoog-Svanberg, Lampic, Bergh, \& Lundkvist, 2003). Добијени резултати показују да, уопштено гледано, постоје позитивни ставови према донирању ооцита, али је већина испитаника резервисана по питању пропагирања донора у медијима. Већина испитаника има и недоумице у вези са донирањем из ВТО процеса, а приликом испитивања анонимности донора и права детета да сазна своје порекло испитаници подржавају супротстављене опције. Иако се ради о истраживању спроведеном на студентској популацији, могуће је извдојити значајне смернице за почетак промоције добровољног давалаштва јајних ћелија у Републици Србији, као и импликације за будућа истраживања.

Кључне речи: донирање јајних ћелија, ставови према донирању, могући донори, промоција донирања, студенти.

\section{INTRODUCTION}

Fertility (the average number of children that a woman gives birth to during the reproductive period of her life) is significantly decreasing in developed and developing countries. The fertility rate in the EU in 2017 ranged from 1.26 (Malta) to 1.90 (France), averaging at 1.59 (Eurostat, 2019). The fertility rate in Serbia is within this range - 1.5 in 2018 (Republic Institute for Statistics, 2019). For simple population growth, a rate of 2.1 is needed; lower values represent a decline in the population. In part, this is due to the modern lifestyle, which is contrary to the requirements of delivering and raising a larger number of children. Higher levels of education and a professional career lead many women to have children later in life, which could be linked to difficulty conceiving (Stöbel-Richter, Goldschmidt, Brähler, Weidner, \& Beutel, 2009; Nargund, 2009). More serious problems with fertility can be found among $10 \%$ of all couples, and roughly $5 \%$ of them will be involuntarily childless (Gnoth et al., 2005). For many countries worldwide, encouraging births and increasing options for couples who are having difficulty conceiving represent an important part of their internal policy. Assisted Reproductive Technologies (ARTs) offer couples with fertility issues multiple options and one of them is the possibility of conceiving with donated eggs.

\section{Egg Donation and Donors}

Oocyte donation is a 'third party' infertility treatment (ESHRE fact sheets 3, 2017), or the inclusion of 'reproductive others' (Freeman, Graham, Ebtehaj, \& Richards, 2014), akin to sperm and embryo donation, and surrogate motherhood. The donated eggs are needed by women who cannot produce their own eggs or are at a high risk of transmitting genetic conditions (ESHRE fact sheets 3, 2017). Egg donation (ED) is a more complex and in- 
vasive procedure than sperm donation. A woman who would like to be a donor must take hormone therapy and undergo aspiration - egg cell extraction. These cells will be fertilized with the sperm of the intended mother's partner, and the embryo then transferred. This is the process of in vitro fertilization (IVF), with the exception that the woman providing the egg (the donor) is not the same woman receiving the embryo (the intended mother). ED allows intended mothers to experience pregnancy and give birth to a child which is genetically not theirs. It is not easy to determine how many women require ED for pregnancy. Studies have shown that 6-15\% of women in their reproductive period have trouble conceiving (Ceballo, Abbey, \& Schooler, 2010; Gnoth et al, 2005; Petz, Janic, \& Craig, 2016; Stanford, 2013). However, the reasons for infertility are numerous and not necessarily related to the quality of the eggs, or the reproductive health of the woman. An estimate can be made based on ESHRE data (The European Society of Human Reproduction and Embryology) for 28 European countries, which indicate that of the roughly 500000 cycles of IVF carried out in Europe in 2013, 39000 were treatments which included donated eggs (Andersen, et al., 2007; ESHRE fact sheets 3,2017 ). The data indicate that in roughly $8 \%$ of all IVF cycles, the use of donated eggs was necessary. Still, we cannot completely rely on this estimation, since in six of the countries donation was not legal, and the data only included couples who managed to obtain a donated egg.

ED is not legal in all European countries: it is illegal in Germany. Some countries allow ED with donor anonymity (France, Greece, Hungary, Italy, Poland, Portugal, Slovenia, and Spain), or with non-anonymous donors who are open to contact when the child comes of age (Austria, Finland, Holland, Sweden, and the United Kingdom). In Serbia, the Law on Biomedically Assisted Fertilization (BMAF) ${ }^{1}$ was passed in 2017 (Official Gazette of RS, 40/2017) requiring donors to be anonymous (Articles 5557). Countries also differ based on the compensation the donor can receive. France allows (only) compensation of the actual expenses incurred during the donation process, a model included in our own laws. "It is strictly prohibited to offer, or provide reproductive cells as gifts, i.e., embryos, to procure monetary or any other type of gain." (Article 32, Section 1, BMAF).

${ }^{1}$ The law is still not being practiced, since until April 2019, a set of guidelines had still not been provided for detailed regulation of gamete donation (nine rulebooks published in the Official Gazette of RS, 27/2019, available at: http://www.pravnoinformacioni sistem.rs/SlGlasnikPortal/eli/rep/sgrs/ministarstva/pravilnik/2019/27/. A reproductive cell bank opened on May 21, 2019 at the Clinic for Gynecology and Obstetrics of the Clinical Center of Serbia (Belgrade). Even though this is important and encouraging news for couples who cannot bring a pregnancy to term without a donated oocyte, it happened that donors were not visiting the bank. It would seem that there is still some lack of clarity regarding the procedure and not much has been done to make ED (or sperm and embryo donation) more relatable to the wider public and potential donors. 
The donor expenses that are covered are related to temporary absence from work, the cost of transport related to the donation process, and compensation for 'excessive damage' which could be incurred on the part of the donor during the process (Article 32). There are researchers who consider financial compensation to be the best means of ensuring a satisfactory number of available cells, since the demand constantly outweighs the supply (Bayefsky, DeCherney, \& Berkman, 2016; Shapiro, 2018). In Europe, Spain provides the greatest financial compensation (roughly 1000e), and is the country with the largest number of egg donors: as many as $50 \%$ of all the donations made in Europe (Pavone, 2018). These donors are anonymous - the employees of Spanish IVF clinics think that revoking anonymity would have a negative impact on the number of donations (Pavone, 2018). But, even if the donor is anonymous, the recommendation is that the parents not hide any information related to the specificities of conception from the child (Ethics Committee of the American Society for Reproductive Medicine, 2013; Golombok, 2015; Pasch, 2018).

There are different types of donors (Purewal \& van der Akker, 2009a), such as patient-donors - individuals taking part in IVF who for some reason decided to donate their reproductive cells or unused embryos. Compensation for donors differs - from completely voluntary materially non-compensated donation, to compensation, or a discount in the price of their own IVF procedure. Non-patient donors are usually known ${ }^{2}$, commercial, voluntary, and potential (Purewal \& van den Akker, 2009a). In Serbia, ED will be possible for IVF patients without compensation, and good-will donors (where, by definition, compensation is not included). All healthy individuals in their reproductive periods can be viewed as potential donors. Egg sharing is a particularly complex topic due to the aforementioned discount in the price of the IVF process. The positive aspect of finding a donor this way is that healthy women are not exposed to (unnecessary) hormone therapy (Simons \& Ahuja, 2005); however, there are issues related to egg sharing, including nonmedical ones such as donors regretting their decisions; circumstances which prevent the female patient - potential donor from giving valid voluntary consent; and the transformation of a reproductive cell into merchandise that can be traded (Blyth \& Golding, 2008).

Facts pertaining to the donation process and donors in general need to be presented to the broader public in a comprehensible, adapted form to help

\footnotetext{
${ }^{2}$ Known donors are individuals who decide to donate to a couple they are acquainted with (friends, relatives). However, their reproductive cells will not be given to that couple, but another couple undergoing IVF, for whom the donor will actually be anonymous. The benefit to the couple who provided the donor is their being moved up to the top of the list for a donation. This type of donation is referred to as known donation, since the individuals decided to donate to help a couple with whom they have close ties. (Thus, these are not non-anonymous donors, which is a variation of commercial donation.)
} 
shape attitudes based on scientific facts. Sadly, research indicates that knowledge of ED is quite limited, especially in the population of individuals who do not have fertility issues (Baykal, Korkmaz, Ceyhan, Goktolga \& Baser, 2008; Chliaoutakis, Koukouli, \& Papadakaki, 2002; Isikoglu et al., 2006; Khalili, Isikoglu \& Ghasemi, 2006; Straehl, Lara, Sa, Reis, \& Rosa, 2017); university education is not related to better familiarity with the donation process, nor issues of fertility in general (García, Vassena, Trullenque, Rodríguez, \& Vernaeve, 2015). Lack of knowledge of ED is one of the more significant factors which drives people away from donation (Gezinski, Karandikar, Carter \& White, 2016; Stevens \& Hayes, 2010).

\section{Attitudes Towards ED}

The social and psychological factors which determine donation are of great importance for clinics, lawmakers, and campaigns. For future parents, potential donors and the future environment of the child to accept this option, research should first focus on the attitudes towards ED, and then, through a carefully designed campaign, support the positive attitudes and work on correcting the negative ones. This activity, defined as the "promotion of the voluntary donation of reproductive cells" is included in the BMAF (Article 48); however, national research into these issues is scarce, so we refer international research results which refer to the general population and potential donors.

A new review study (Platts et al., 2019) on attitudes towards ED among potential donors and the general population sums up the results of 39 studies. Only 8 studies used a previously constructed validated instrument, as attitudes towards ED can be studied with a set of questions which the researchers consider relevant for the given environment in the given moment. The respondents in the selected studies express positive attitudes towards ED; however, the percentages differ and range from 50,8 to 91,8 (Platts et al., 2019). The attitudes regarding whether parents should inform their child of its genetic origin were also mostly positive (Platts et al., 2019). However, there are also studies where the respondents mostly indicated that a child should never learn anything about the conception: for example, a study in Turkey (Isikoglu et al., 2006) and Iran (Khalili et al., 2006). The same review study indicates that there is no clear consensus regarding the anonymity of the donors and the potential contact between the donor and the child.

The research of Purewal and van der Akker (2009b) focused on the attitudes and intentions for voluntary ED and included 349 women (nonpatients), average age 27,8 years. One-third of them indicated a readiness for non-anonymous ED, which is a legal option in GB where the study was carried out. The results indicated that marital, socio-economic and professional status are not related to readiness to donate; women who expressed their readiness to donate were older, had experienced miscarriages more of- 
ten, and were less educated (compared to those unwilling to donate their eggs). Potential donors - women aged 25 to 30 - were the focus of a Swedish study at a time when that option became legal in that country (SkoogSvanberg, Lampic, Bergh, \& Lundkvist, 2003a). 17\% of them were ready to consider ED, 39\% were against, $44 \%$ were doubtful. One-third did not think that the child should learn the identity of the donor, but a similar number indicated that they would be happy if the child would contact them in the future (Skoog-Svanberg et al., 2003a). An adapted version of the questionnaire was used in our study. The authors also compared the responses of men and women (Skoog-Svanberg, Lampic, Bergh, \& Lundkvist, 2003b). On a sub-scale of the attitudes on ED in general, women were more willing to support donating/receiving eggs, but when evaluating the claim "Egg donation is a good way to help childless couples" there was no difference between men and women (see Table 1). Although Platts et al. (2019) indicated to consensus regarding the issue of donor anonymity, among the Swedish respondents, both men and women expressed agreement with the claim a child should find out its genetic origins, and that parents should be honest with the child; they did not oscillate in their responses to the claim that parents should decide whether to tell their child and if it will disrupt the parent-child relationship - they mostly disagreed with these claims (for the formulation of the items and our results please see Table 3 ). Clearly they had a consistent attitude, even though ED had only recently become legal in their country. However, Sweden had for years practiced insemination via a sperm donor, and in 1984 ratified a law that children conceived in such a way had the right to learn the identity of the donor (Skoog-Svanberg et al., 2003b), thus they knew about gamete and non-anonymous donors.

A public opinion survey in the USA (Lee, Farland, Missmer, \& Ginsburg, 2017) indicated that $16 \%$ of the respondents consider egg and sperm donation unacceptable (4\% do not accept IVF as a treatment); $80 \%$ were in favor of gamete donation, while $90 \%$ from this last group considered that donors should be provided with financial compensation. A study carried out on a student population, also in the US (Lester, Furnham \& Salem, 2010), indicated that more than $90 \%$ of the respondents approve of egg and sperm donation - which is somewhat higher than in the general population. The second study carried out on a student population in the US (Stevens \& Hayes, 2010) showed that $23 \%$ of the respondents considered donating their own egg cells, while $43 \%$ stated there were not ready for that option.

This research was carried out with the aim of determining the attitudes of students and the possible differences between young women and men towards: a) ED in general; b) some specific circumstances regarding donation; and c) openness related to the child's genetic origin. Even though the study was carried out on a suitability sample, the results could be a good starting point for planning a promotional campaign. The im- 
portance of the population from which the sample was extracted is explained in the Discussion.

\section{METHOD}

Sample and Procedure

The sample of respondents consisted of 503 students of the University of Nis, 206 young men and 297 young women (aged from 18 to 27; $M=$ $20.57, S D=1.41$ ). The research was carried out in various faculties in the spring of 2019. The respondents were informed about the goals of the study, and gave their oral consent to participate in the research. They were informed that they could, at any time, without explanation, refuse to complete the questionnaire.

\section{Measures}

At the very beginning of the questionnaire, a short text was provided which informed the respondents that there is a law which allows gamete donation in the RS, to ensure that the they understood that this was an actual possibility of overcoming infertility in Serbia. They then indicated whether they had previously been aware of the existence of such a law, while young women also answered the question about willingness to donate oocyte.

An attitude scale was provided on ED, based on the scale designed by a group of Swedish authors to study egg donation (Skoog-Svanberg, Lampic, Bergh, \& Lundkvist, 2003). The content of the items was adapted to the general population: detailed knowledge of the donation process, or IVF, was not assumed based on the research context. The scale had three sections: attitudes on ED in general; an estimation of the specific circumstances regarding donation; and attitudes towards openness, or keeping secrets regarding the child's genetic origin. Data analysis included descriptive statistics, which is rare in opinion surveys regarding ED (Baykal et al., 2008; Gezinski et al., 2016; Kenney \& McGowan, 2010; Khalili, et al., 2006; Isikoglu et al., 2006; Lee et al., 2017; Skoog-Svanberg et al., 2003a; Skoog-Svanberg et al., 2003b; Stöbel-Richter et al., 2009; Thaldar, 2020). The study of the metric characteristics of the scale using an internal consistency method at this point is inapplicable, since there is a notable oscillation in the attitudes. This is understandable since the phenomenon is new for the respondents - there was no time to form a consistent attitude. The issue will be discussed in the Discussion.

\section{RESULTS}

$25,7 \%$ of the young men $39,1 \%$ of the young women indicated they knew of the BMAF. Roughly $30 \%$ of them stated that they would 
donate their own eggs; $15 \%$ refused that possibility; the remaining young women opted for the I am not sure option.

Table 1 indicates that most of the respondents had positive attitudes towards ED (items 1, 2 and 5). They do not think that a couple should remain childless if they cannot have their own children (item 4). Item 3 studies the attitude towards the second option which is available to couples - adoption. All of the responses of the young women and men differ significantly; the young women indicate a greater openness towards the option of donation.

Table 1. Attitudes toward ED in general

\begin{tabular}{|c|c|c|c|c|}
\hline \multirow[t]{2}{*}{ Item } & & $\begin{array}{c}\text { Young } \\
\text { men } \\
\text { N } 206 \\
\end{array}$ & $\begin{array}{l}\text { Young } \\
\text { women } \\
\text { N } 297\end{array}$ & \multirow{2}{*}{$\begin{array}{l}\text { Significance } \\
\text { of the } \\
\text { difference } \\
\chi^{2} \text { test }\end{array}$} \\
\hline & responses* & Percentage & Percentage & \\
\hline \multirow{4}{*}{$\begin{array}{l}\text { 1. If my friend/acquaintance } \\
\text { wanted to donate her eggs, I } \\
\text { would support her decision. }\end{array}$} & 1 & 71,4 & 87,5 & \multirow{4}{*}{$\begin{array}{c}\chi^{2}=19,99 \\
d f=3 \\
p=.000\end{array}$} \\
\hline & 2 & 22,3 & 8,1 & \\
\hline & 3 & 2,9 & 2,7 & \\
\hline & 4 & 3,4 & 1,7 & \\
\hline \multirow{4}{*}{$\begin{array}{l}\text { 2. If my friend/acquaintance } \\
\text { wanted to get donated egg } \\
\text { cells, I would support her } \\
\text { decision. }\end{array}$} & 1 & 69,4 & 86,5 & \multirow{4}{*}{$\begin{array}{c}\chi^{2}=23,20 \\
d f=3 \\
p=.000\end{array}$} \\
\hline & 2 & 22,3 & 6,7 & \\
\hline & 3 & 5,8 & 3,4 & \\
\hline & 4 & 2,4 & 3,4 & \\
\hline \multirow{4}{*}{$\begin{array}{l}\text { 3. If a couple is infertile, } \\
\text { adoption should be their first } \\
\text { choice. }\end{array}$} & 1 & 35,0 & 23,9 & \multirow{4}{*}{$\begin{array}{c}\chi^{2}=29,07 \\
d f=3 \\
p<.01\end{array}$} \\
\hline & 2 & 35,4 & 47,1 & \\
\hline & 3 & 18,4 & 15,2 & \\
\hline & 4 & 11,2 & 13,8 & \\
\hline \multirow{4}{*}{$\begin{array}{l}\text { 4. If you cannot have children } \\
\text { of your own, then you should } \\
\text { not have children at all. }\end{array}$} & 1 & 3,9 & 2,7 & \multirow{4}{*}{$\begin{array}{c}\chi^{2}=10,62 \\
d f=3 \\
p=.001\end{array}$} \\
\hline & 2 & 9,2 & 2,0 & \\
\hline & 3 & 79,1 & 90,2 & \\
\hline & 4 & 7,8 & 5,1 & \\
\hline \multirow{4}{*}{$\begin{array}{l}\text { 5. Egg donation is a good way } \\
\text { of helping couples without } \\
\text { children. }\end{array}$} & 1 & 71,4 & 85,2 & \multirow{4}{*}{$\begin{array}{c}\chi^{2}=16,45 \\
d f=3 \\
p=.000\end{array}$} \\
\hline & 2 & 14,6 & 7,1 & \\
\hline & 3 & 8,3 & 2,0 & \\
\hline & 4 & 5,8 & 5,7 & \\
\hline
\end{tabular}

* The following responses were offered: $1=\mathrm{I}$ agree; 2 = I neither agree nor disagree (I am neutral); 3 = I disagree; 4 = I cannot form an opinion.

Table 2 shows the frequency of the responses and differences in terms of gender in evaluating some specific circumstances related to donation. No responses are favored by most of the respondents at a rate of $70-80$ or even $90 \%$, results similar to those in Table 1 . Since we are dealing with attitudes which are significant for the success of the donation campaign, they will be analyzed further in the Discussion. 
Table 2. An evaluation of the specific circumstances related to ED

\begin{tabular}{|c|c|c|c|c|}
\hline \multirow[t]{2}{*}{ Item } & & $\begin{array}{l}\text { Young } \\
\text { men } \\
\text { N } 206 \\
\end{array}$ & $\begin{array}{l}\text { Young } \\
\text { women } \\
\text { N } 297\end{array}$ & \multirow[t]{2}{*}{$\begin{array}{l}\text { Significance } \\
\text { of the } \\
\text { difference }\end{array}$} \\
\hline & responses* & Percentage & Percentage & \\
\hline \multirow{4}{*}{$\begin{array}{l}\text { 6. Women undergoing IVF } \\
\text { should be asked to donate the } \\
\text { cells which remain unused. }\end{array}$} & 1 & 30,1 & 24,9 & \multirow{4}{*}{$\begin{array}{c}\chi^{2}=8,52 \\
d f=3 \\
p<.05\end{array}$} \\
\hline & 2 & 34,0 & 27,6 & \\
\hline & 3 & 13,6 & 13,5 & \\
\hline & 4 & 22,3 & 34,0 & \\
\hline \multirow{4}{*}{$\begin{array}{l}\text { 7. Women who would like to } \\
\text { undergo sterilization (tubal } \\
\text { ligation) should be asked to donate } \\
\text { their eggs before the procedure. }\end{array}$} & 1 & 48,5 & 55,6 & \multirow{4}{*}{$\begin{array}{c}\chi^{2}=12,06 \\
d f=3 \\
p<.01\end{array}$} \\
\hline & 2 & 29,6 & 17,5 & \\
\hline & 3 & 8,3 & 7,1 & \\
\hline & 4 & 13,6 & 19,9 & \\
\hline \multirow{4}{*}{$\begin{array}{l}\text { 8. Donor propagation in the } \\
\text { media is a good way of } \\
\text { recruiting women for ED. }\end{array}$} & 1 & 30,1 & 37,9 & \multirow{4}{*}{$\begin{array}{c}\chi^{2}=10,73 \\
d f=3 \\
p=.01\end{array}$} \\
\hline & 2 & 43,7 & 30,3 & \\
\hline & 3 & 12,1 & 11,4 & \\
\hline & 4 & 14,1 & 18,5 & \\
\hline \multirow{4}{*}{$\begin{array}{l}\text { 9. A woman who donates her eggs } \\
\text { and the couple who will receive } \\
\text { them should remain anonymous } \\
\text { and unknown to one another. }\end{array}$} & 1 & 39,8 & 27,6 & \multirow{4}{*}{$\begin{array}{c}\chi^{2}=8,54 \\
d f=3 \\
p<.05\end{array}$} \\
\hline & 2 & 29,1 & 34,0 & \\
\hline & 3 & 18,9 & 21,9 & \\
\hline & 4 & 12,1 & 16,5 & \\
\hline \multirow{4}{*}{$\begin{array}{l}\text { 10. The egg donor should have } \\
\text { some form of relationship (that } \\
\text { of a friend/cousin) with the } \\
\text { couple getting the egg. }\end{array}$} & 1 & 15,0 & 10,4 & \multirow{4}{*}{$\begin{array}{c}\text { NS } \\
\left(\chi^{2}=7,39\right. \\
d f=3)\end{array}$} \\
\hline & 2 & 42,7 & 38,0 & \\
\hline & 3 & 32,0 & 34,0 & \\
\hline & 4 & 10,2 & 17,5 & \\
\hline \multirow{4}{*}{$\begin{array}{l}\text { 11. Only women under the age } \\
\text { of } 43 \text { should be allowed to } \\
\text { receive donated eggs. }\end{array}$} & 1 & 25,7 & 20,2 & \multirow{4}{*}{$\begin{array}{c}\text { NS } \\
\left(\chi^{2}=5,99\right. \\
d f=3)\end{array}$} \\
\hline & 2 & 27,7 & 22,2 & \\
\hline & 3 & 32,5 & 39,1 & \\
\hline & 4 & 14,1 & 18,5 & \\
\hline
\end{tabular}

* The following responses were offered: 1 = I agree; 2 = I neither agree nor disagree (I am neutral); 3 = I disagree; 4 = I cannot form an opinion; NS = the difference is not statistically significant. 
Table 3 shows the current attitudes of the respondents towards keeping the child's genetic origin secret i.e., donor anonymity. Both the young women and men express different attitudes - namely, between the rights of the child (items 12, 15 and 17), the rights of the parents to decide whether or not to reveal the circumstance of conception (13), and the prevention of conflicts this knowledge could bring (14 and 16).

Table 3. Attitudes towards openness, or keeping secret the child's genetic origin

\begin{tabular}{|c|c|c|c|c|}
\hline \multirow[t]{2}{*}{ Item } & \multirow[t]{2}{*}{$\begin{array}{c}\text { Offered } \\
\text { responses* }\end{array}$} & $\begin{array}{c}\text { Young } \\
\text { men } \\
N 206\end{array}$ & $\begin{array}{c}\text { Young } \\
\text { women } \\
N 297\end{array}$ & \multirow[t]{2}{*}{$\begin{array}{l}\text { Significance } \\
\text { of the } \\
\text { difference }\end{array}$} \\
\hline & & Percentage & Percentage & \\
\hline 12. Children conceived with & 1 & 57,3 & 57,6 & \\
\hline the help of a donor have the & 2 & 23,8 & 20,5 & NS \\
\hline right to learn their genetic & 3 & 7,3 & 7,4 & $\left(\chi^{2}=1,321\right.$ \\
\hline $\begin{array}{l}\text { origin (that is, who the } \\
\text { donor is). }\end{array}$ & 4 & 11,7 & 14,5 & $d f=3)$ \\
\hline 13. Parents should decide & 1 & 41,7 & 43,4 & \\
\hline whether (or not) to reveal to & 2 & 28,2 & 25,6 & NS \\
\hline their children what their & 3 & 21,8 & 19,5 & $\left(\chi^{2}=1,925\right.$ \\
\hline genetic origin is. & 4 & 8,3 & 11,4 & $d f=3)$ \\
\hline 14. It is in the best interest & 1 & 16,0 & 10,4 & \\
\hline of the child to never be & 2 & 30,1 & 29,3 & NS \\
\hline provided with information & 3 & 40,3 & 46,8 & $\left(\chi^{2}=4,174\right.$ \\
\hline on its genetic origin. & 4 & 13,6 & 13,5 & $d f=3)$ \\
\hline 15. When it becomes an & 1 & 62,1 & 67,3 & \\
\hline adult, the child will have the & 2 & 22,3 & 13,8 & NS \\
\hline right to learn the identity of & 3 & 6,8 & 6,7 & $\left(\chi^{2}=6,914\right.$ \\
\hline its donor. & 4 & 8,7 & 12,1 & $d f=3)$ \\
\hline 16. The relationship & 1 & 23,3 & 24,2 & \\
\hline between the parents and the & 2 & 40,8 & 35,4 & NS \\
\hline child can be compromised if & 3 & 23,3 & 28,3 & $\left(\chi^{2}=2,172\right.$ \\
\hline $\begin{array}{l}\text { the child finds out its } \\
\text { genetic origin. }\end{array}$ & 4 & 12,6 & 12,1 & $d f=3)$ \\
\hline 17. The parents should be & 1 & 55,3 & 65,3 & \\
\hline honest with their children & 2 & 27,7 & 17,5 & $\chi^{2}=9,262$ \\
\hline regarding their genetic & 3 & 6,8 & 4,7 & $d f=3$ \\
\hline origin. & 4 & 10,2 & 12,5 & $p<.05$ \\
\hline
\end{tabular}

$*$ The following responses were offered: $1=\mathrm{I}$ agree; $2=\mathrm{I}$ neither agree nor disagree (I am neutral); 3 = I disagree; 4 = I cannot form an opinion; NS = the difference is not statistically significant. 


\section{DISCUSSION}

Increase in fertility by assisted reproduction is an important issue in many countries. Serbia allowed the use of donated gametes in 2017 and then in 2019 (however, this is not yet possible in practice). A shortage of oocytes is expected, and the study focused on the attitudes towards ED. To determine if the respondents consider ED a realistic possibility in the RS, we first provided information on the law itself, and evaluated if they had been aware of it - most had not. The situation may have changed slightly, as the media have reported on the opening of a gamete bank. The change is not considered significant, since the law received media coverage. The population from which the sample was extracted is significant for the practice of gamete donation: they represent potential donors, and are the potential carriers of positive attitudes in the community and long-term environment of couples who require a donation. Informing them about donation will require more than news channels. During the study - prior to the promotion of donation - one-third of the female students stated that they would be ready to donate their eggs. These findings are in agreement previous ones (Purewal \& van der Akker, 2009b; Stevens \& Hayes, 2010; Skoog-Svanberg et al., 2003a; Skoog-Svanberg et al., 2003b).

The basic research problem was the analysis of students' attitudes towards ED. The study was carried out on a suitable sample which is not representative of the entire population, but is significant for the success of donation. The obtained data are significant for the establishment of adequate goals of future campaigns. Since we are dealing with a new phenomenon, unfamiliar to the respondents, the attitudes towards it could not be fossilized. This provides a greater possibility for shaping attitudes, but could also be unfavorable - if the public primarily or frequently encounters negative information regarding donation, their attitudes will sway in that direction. When it comes to supporting donation as opposed to supporting adoption (items 1, 2 and 5 as opposed to item 3, Table 1), it should be said that qualitative research of couples who have difficulty conceiving indicates that they frequently opt for what enables them to (at least in part) have a biological connection with the child (Golombok, 2015), seeking out an option which is closest to the 'natural' one. This should be expected, as 'blood' kinship ties are something that people attach a lot of importance to (Freeman et al., 2014). However, a campaign which supports donation should not at the same time discourage adoption. Both options should be supported, which is likely what our respondents also thought. In general, the students are ready to support egg donation (roughly $70 \%$ of the young men and close to $90 \%$ of the young women); only a proportionally small number expressed an unambiguously negative attitude. These findings are close to the upper range of support shown for donation (Platts et al., 2019) and are an indication that a campaign aimed at future donations and spreading positive attitudes in the environment could have a positive impact, since 
the results pointed out current existence of positive attitudes. The young women were more ready to support ED compared to young man. Differences in terms of gender were also obtained in a study carried out on a sample of young adults (Skoog-Svanberg et al., 2003b). Perhaps the claims provoked greater empathy and solidarity with a woman who requires such a donation among the female respondents. This result is encouraging in the sense of donor recruitment, but does not mean that young men, or men in general, should be neglected in this campaign. They are partners and members of the environment which should support donation, and messages calling to action must be aimed at both women and men.

The respondents were also asked to express their attitudes to some specific circumstances regarding donation (Table 2 ). There were no preferred responses, except for the second item - roughly one half believe that women who opt for tubal ligation should be asked beforehand if they would like to donate their eggs. Special attention should be paid to the attitudes pertaining to items six and eight. Only one-third of the young men and one-fourth of the young women in the sample think that women undergoing IVF should be asked to donate their unused eggs. The law does allow voluntary donors and patient donors; since offering/accepting payment is not allowed, it is necessary to maximize the chances which are available. This means building a positive attitude towards donation from the IVF process. In light of the greater empathy towards women who are having difficulty conceiving, perhaps the young women do not agree as much with asking for donations from patients, since that could cause additional stress. 'Egg sharing' is an option that experts are divided on, as was explained in the Introduction (Blyth \& Golding, 2008). It will be a challenge for the campaign to point out the invaluable help which donation offers, but without creating a sense of guilt among women undergoing IVF who do not want to share their eggs. In the case of the item eight, propagating donors in the media, (only) one-third of the young men and slightly more of the young women expressed their agreement. The lack of certainty on this issue can be seen as a sign of the lack of confidence in 'advertising' gamete donation. This is understandable, since it illustrates a situation in which an egg is a type of merchandise. It will be necessary for the videos in the campaigns not to resemble familiar advertisements, but short life stories. Items 9 and 10 show oscillations among the respondents regarding the anonymity of the donors; more young men than women agree that both the donor and the couple should remain anonymous to each other (roughly $40 \%$ of the young men, slightly less than $30 \%$ of the young women; with a significant percentage of the "I neither agree, nor disagree" option). A little over one-third do not agree that the donor and couple should become friends; but there were quite a few neutral responses here. The issue is a very complex one. Today, the predominant attitude is that the child has the right to find out the identity of the donor, and numerous European countries, which had previously begun the donation process, are abolishing donor anonymity. 
Serbia has yet to go down the road of accepting donation, so there is currently more sense in supporting anonymity prescribed by law. Even in a country where non-anonymous sperm donation existed prior to the introduction of egg donation, close to $50 \%$ of men and women agreed that an egg donor and the couple should remain anonymous to each other (Skoog-Svanberg et al., 2003b).

Another complex issue is keeping identities secret as opposed to the right of the child to learn its genetic origin and the identity of the donor. The respondents' answers varied here, attempting to support both the choice of the parents (item 13) and the rights of the child (items 12 and 15). The idea that parents should be honest regarding genetic origin (item 17 ) is supported by $55 \%$ of the young men and $65 \%$ of the young women - the percentages are most likely not greater due to the fear that the relationship between the parents and child will be compromised (item 16). It is absolutely not in the best interest of the child to never get access to information regarding its genetic origin (Ethics Committee of the American Society for Reproductive Medicine, 2013; Golombok, 2015; Pasch, 2018), which is currently recognized by a little less than half of the respondents, with one-third undecided (item 14). In an essentially similar claim, worded differently, we have a greater percentage of agreement - between 60 and $70 \%$ agree that the child has the right to find out the identity of its donor (item 15). However, this right and the best interest of the child are not recognized by the BMAF at the moment, since donor anonymity is required. The wider public should see that such an option is a valid choice in the beginning, with the idea that it should be overcome in the future; parents should certainly be supported in their openness towards their child, irrespective of whether donor identity can be revealed.

The results obtained from this student population should be studied on samples from other populations as well. However, it is still possible to provide some guidelines for the first steps in promoting voluntary ED. Attitudes towards egg donation are generally positive - which is a very good start, but there are clear indications which specific attitudes attention should be focused on. The first step should be the realization of a positive attitude towards the campaign itself - not as an advertisement for cell trade, but a possibility for a woman to give another woman a priceless gift - the gift of motherhood. Rendering the option of donation from IVF, or egg sharing, more relatable should be done very carefully. The goal is not to create added pressure on women who are already in a stressful situation. "You can spread joy", "You can give hope" would be the type of slogan which is clear enough, positive and which provides the option to choose. If the campaign successfully creates an image of donors as exceptional people who took a great step - which is true - parents will find it easier to be open towards their children, and children due to the specific nature of conception will not be shunned in their environment. 
The potentially most sensitive part of the promotion is bridging the gap between donor anonymity and the rights of the child.

It would be good for upcoming research to include the attitudes of other age and social groups, to better define the goals and messages of the campaign. Existing knowledge and attitudes of reproductive health and the donation process is worth studying, since theirs important positive, as well as negative effect to voluntary donation.

\section{REFERENCES}

Andersen, A. N., Goossens, V., Gianaroli, L., Felberbaum, R., de Mouzon, J., \& Nygren, K. G. (2007). Assisted reproductive technology in Europe, 2003. Results generated from European registers by ESHRE. Human Reproduction 22(6), 1513-1525. doi:10.1093/humrep/dem053

Bayefsky, M. J., DeCherney, A. H., Berkman, B. E. (2016). Compensation for egg donation: a zero-sum game. Fertility and Sterility, 105(5), 1153-1154. doi: 10.1016/j.fertnstert.2016.01.019

Baykal, B., Korkmaz, C., Ceyhan, S.T., Goktolga, U., \& Baser, I. (2008). Opinions of infertile Turkish women on gamete donation and gestational surrogacy. Fertility and Sterility, 89(4), 817-822. doi: 10.1016/j.fertnstert.2007.04.022

Blyth, E., \& Golding, B. (2008). Egg sharing: a practical and ethical option in IVF? Review of Obstetrics \& Gynecology, 3(4), 465-473.

Bracewell-Milnes, T., Saso, S., Bora, S., Ismail, A. M., Al-Memar, M., Hamed, A. H., Abidalla, H., \& Thum, M.-Y. (2016). Investigating psychosocial attitudes, motivations and experiences of oocyte donors, recipients and egg sharers: a systematic review. Human Reproduction Update, 22(4), 450-465. doi:10.1093/ humupd/dmw006

Ceballo, R., Abbey, A., \& Schooler, D. (2010). Perceptions of women's infertility: what do physicians see? Fertility and Sterility, 93(4), 1066-1073. doi: 10.1016/j.fertnstert.2008.11.019

Chliaoutakis, J. E., Koukouli, S., Papadakaki, M. (2002). Using attitudinal indicators to explain the public's intention to have recourse to gamete donation and surrogacy. Human Reproduction, 17, 2995-3002. doi: 10.1093/humrep/17.11.2995

Eurostat (2019). Fertility statistics. https://ec.europa.eu/eurostat/statistics-explained/index. php/Fertility_statistics

ESHRE fact sheets 3 (2017). Egg donation. Посећено 15. марта 2018. године на https://www.eshre.eu/Press-Room/Resources

Ethics Committee of the American Society for Reproductive Medicine. Informing offspring of their conception by gamete or embryo donation: a committee opinion. (2013). Fertility and Sterility, 100(1), 45-49. doi:10.1016/j.fertnstert. 2013.02.028

Freeman, T., Graham, S., Ebtehaj, F., \& Richards, M. (2014). Relatedness in Assisted Reproduction. Families, Origins and Identities. Cambridge University Press.

García, D., Vassena, R., Trullenque, M., Rodríguez, A., \& Vernaeve, V. (2015). Fertility knowledge and awareness in oocyte donors in Spain. Patient Education and Counseling, 98, 96-101. doi: http://dx.doi.org/10.1016/j.pec.2014.10.009

Gezinski, L. B., Karandikar, S., Carter, J., \& White, M. (2016). Exploring Motivations, Awareness of Side Effects, and Attitudes among Potential Egg Donors. Health \& Social Work, 41(2), 75-83. doi:10.1093/hsw/hlw005 
Gnoth, C., Godehardt, E., Frank-Herrmann, P., Friol, K., Tigges, J., \& Freundl, G. (2005). Definition and prevalence of subfertility and infertility. Human Reproduction, 20(5), 1144-1147. doi:10.1093/humrep/deh870

Golombok, S. (2015). Modern Families: Parents and Children in New Family Forms. Cambridge University Press.

Isikoglu, M., Senol, Y., Berkkanoglu, M., Ozgur, K., Donmez, L., \& Stones-Abbasi, A. (2006). Public opinion regarding oocyte donation in Turkey: fist data from a secular population among the Islamic world. Human Reproduction, 21, 318323. doi:10.1093/humrep/dei274

Kenney, N. J., \& McGowan, M. L. (2010). Looking back: egg donors' retrospective evaluations of their motivations, expectations, and experiences during their first donation cycle. Fertility and Sterility, 93(2), 455-466. doi:10.1016/j.fertnstert. 2008.09.081

Khalili, M., Isikoglu, M., \& Ghasemi, M. (2006). Attitudes of Christians and Muslims to an oocyte donation program in ran. Eubios Journal of Asian and International Bioethics, 16(3), 66-71. Retrieved from https://www.eubios.info/EJAIB52006.pdf

Lee, M. S., Farland, L. V., Missmer, S. A., \& Ginsburg, E. S. (2017). Limitations on the compensation of gamete donors: a public opinion survey. Fertility and Sterility, 107(6), 1355-1363.e4. doi:10.1016/j.fertnstert.2017.03.001

Lester, D., Furnham, A., \& Salem, N. (2010). Attitudes toward Egg and Sperm Donation. Psychological Reports, 106(2), 579-580. doi:10.2466/pr0.106.2.579-580

Nargund, G. (2009). Declining birth rate in Developed Countries: A radical policy rethink is required. Facts, Views \& Vision in Obstetrich, Gynaecology and Reproductive Health, 1 (3): 191-193.

Pasch, L. A. (2018). New realities for the practice of egg donation: a family-building perspective. Fertility and Sterility, 110(7), 1194-1202. doi:10.1016/j.fertnstert. 2018.08.055

Pavone, V. (2018). 50\% of european egg donation happens in Spain. Why? International medical travel journal. Преузето 12.2. 2019. године са https://www.imtj.com/articles/50-european-egg-donation-happens-spain-why/.

Petz, J. D., Janic, A., Craig, \& L. B. (2016). Ethnic and racial differences in the prevalence of infertility: national survey of family growth (NSFG). Fertility and Sterility, 103(6), supp. e8. doi: https://doi.org/10.1016/j.fertnstert.2016. 07.030

Platts, S., Bracewell-Milnes, T., Saso, S., Jones, B., Parikh, R., \& Thum, M.-Y. (2019). Investigating attitudes towards oocyte donation amongst potential donors and the general population: a systematic review. Human Fertility, 113. doi:10.1080/14647273.2019.1602736

Purewal, S., \& van den Akker, O.B.A. (2009a). Systematic review of oocyte donation: investigating attitudes, motivations and experiences. Human Reproduction Update, 15(5), 499-515.

Purewal, S., \& van den Akker OBA. (2009b). Attitudes and intentions towards volunteer oocyte donation. Reproductive Biomedicine Online, 19(suppl 1), 19-26. doi: https://doi.org/10.1016/S1472-6483(10)60059-4

Rašević, M. (2002). Voljna sterilizacija u Srbiji: nezadovoljena potreba? Stanovništvo, $1(4), 15-33$.

Statistical Office of the Republic of Serbia (2019). Announcement - Vital events, 2018. https://publikacije.stat.gov.rs/G2019/Pdf/G20191177.pdf [In Serbian]

Shapiro, D. B. (2018). Payment to egg donors is the best way to ensure supply meets demand. Best Practice \& Research Clinical Obstetrics \& Gynaecology, 53, 73-84. 
Simons, E.G., \& Ahuja, K. K. (2005). Egg-sharing: an evidence based solution to donor egg shortages. The Obstetrician \& Gynaecologist, 7, 112-116. doi: https://doi.org/10.1576/toag.7.2.112.27069

Skoog-Svanberg, A., Lampic, C., Bergh, T., \& Lundkvisk, Ö. (2003a). Public opinion regarding oocyte donation in Sweden. Human Reproduction, 18, 1107-1114. doi: 10.1093/humrep/deg222

Skoog-Svanberg, A. Lampic, C., Bergh, T., \& Lundkvisk, Ö. (2003b). Characterization of potential oocyte donors in Sweden. Human Reproduction, 18(10), 2205-2215. doi:10.1093/humrep/deg398

Stanford, J. B. (2013). What is the true prevalence of infertility? Fertility and Sterility, 99(5), 1201-1202. doi: https://doi.org/10.1016/j.fertnstert.2012.12.006

Stevens, J.B., \& Hayes, C. (2010). Perceptions regarding oocyte donation in a group of female college students. MCN the American Journal of Maternal Child Nursing, 35, 40-46. doi: 10.1097/01.NMC.0000366809.52208.60.

Stöbel-Richter, Y., Goldschmidt, S., Brähler, E., Weidner, K., \& Beutel, M. (2009). Egg donation, surrogate mothering, and cloning: attitudes of men and women in Germany based on a representative survey. Fertility and Sterility, 92(1), 124-130. doi:10.1016/j.fertnstert.2008.05.015

Straehl, J., Lara, L., Sa, M.F.S., Reis, R.M., \& Rosa, E.S.A. (2017) What do infertile women think about oocyte reception, oocyte donation, and child adoption? Revista Brasileira de Ginecologia e Obstetricia / Rbgo Gynecology and Obstetrics, 39, 282-287. doi: 10.1055/s-0037-1603742

Thaldar D (2020) Egg donors' motivations, experiences, and opinions: A survey of egg donors in South Africa. PLoS ONE 15(1): e0226603. https://doi.org/10. 1371/journal. pone. 0226603

Zakon o biomedicinski potpomognutoj oplodnji - Law on Biomedically Assisted Fertility (2017). Available at: http://www.pravno informacioni sistem.rs/SlGlasnikPortal/ eli/rep/sgrs/skupstina/zakon/2017/40/1

\section{ДОНИРАЊЕ ЈАЈНИХ ЋЕЛИЈА: ИСТРАЖИВАЫЕ СТАВОВА СТУДЕНАТА ПРЕМА ДОНИРАҢУ}

Јелена Опсеница Костић, Милица Митровић, Дамјана Панић

Универзитет у Нишу, Филозофски факултет, Ниш, Република Србија

\section{Резиме}

Донирање јајних ћелија је поступак потпомогнуте репродукције који укључује тзв. репродуктивне друге у процес зачећа. Донацијом ооцита се могућности превазилажења стерилитета повећавају, али донирање повлачи са собом и неке дилеме, које су различито решене у европским земљама. У Републици Србији дозвољено је анонимно добровољно донирање ооцита, а донори могу бити жене из опште популације и жене укључене у ВТО процес. Закон изричито забрањује стицање финансијске користи од донирања - донори добијају само компензацију реалних трошкова и, евентуално, накнаду „прекомерне штете” настале током процеса. Ово је нов феномен у нашем друштву, за који и са̂м закон предвиђа промоцију. Да би кампања била одговарајућа, неопходно је упознати актуелне ставове. Ово истраживање спроведено је у циљу истраживања ставова студената према донирању јајних ћелија $(\mathrm{N}=503$; 206 младића, 297 девојака). Популација младих којој узорак припада је вишеструко 
значајна за успостављање праксе донирања гамета: они представљају и могуће доноре и могуће носиоце позитивних ставова у заједници, као и дугорочно животно окружење парова којима је донација потребна. У истраживању је употребљен упитник направљен по угледу на скалу шведских аутора за испитивање ставова могућих донора (Skoog-Svanberg, Lampic, Bergh, \& Lundkvist, 2003). Добијени резултати показују да, уопштено гледано, постоје позитивни ставови према донирању ооцита, али је већина испитаника резервисана по питању пропагирања донора у медијима. Већина испитаника има и недоумице у вези са донирањем из ВТО процеса, а приликом испитивања анонимности донора и права детета да сазна своје порекло, испитаници показују колебање, односно подржавају супротстављене могућности. Иако се ради о истраживању спроведеном на студентској популацији, могуће је издвојити значајне смернице за почетак промоције добровољног донирања јајних ћелија у Републици Србији. Чини се да први корак треба да буде стварање позитивног става према самој кампањи - то није реклама за трговину ћелијама, то је представљање могућности за непроцењиви дар који жене могу дати другим женама - дар мајчинства. Требало би приближити могућност донирања из ВТО процеса, односно дељење јајних ћелија, али врло опрезно, јер циљ није стварање додатног притиска на жене које се већ налазе у стресној ситуацији. „Можеш да поделиш радост”, ,можеш да даш наду” био би тип слогана који је довољно јасан, позитиван и оставља могућност избора. Уколико промоција успе да створи слику о донорима као изузетним људима који су се одлучили на велики корак - што јесте истина, родитељима ће бити лакше да буду отворени према деци, а деца због специфичног начина зачећа неће бити одбачена у средини, тј. били би усмерени и ти ставови. Вероватно најосетљивији део промоције је усаглашавање анонимности донора са правима детета. Било би добро да истраживања у наредном периоду обухвате ставове других узрасних и друштвених група, ради бољег дефинисања циљева и порука кампање. Вреди истражити и знање о репродуктивном здрављу и процесу донирања, јер и то може бити озбиљна препрека добровољном давалаштву јајних ћелија. 